Analysis

\title{
Climate justice, commons, and degrowth
}

\author{
Patricia E. (Ellie) Perkins \\ Faculty of Environmental Studies, York University, Toronto, Ontario M3J 1P3, Canada
}

\begin{abstract}
A B S T R A C T

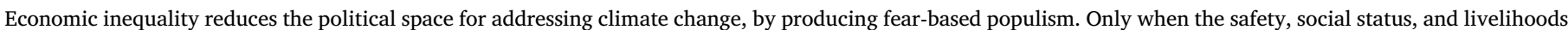

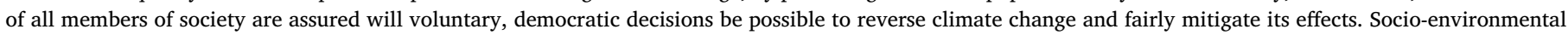

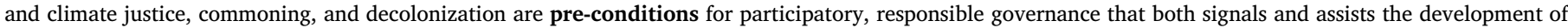

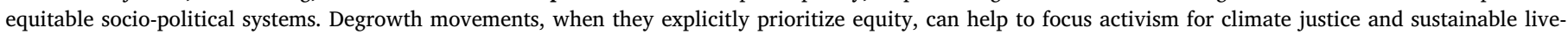
lihoods.

This paper overviews the theoretical grounding for these arguments, drawing from the work of ecofeminist and Indigenous writers.

Indigenous (and also ecofeminist) praxis is grounded in activists' leadership for commoning and resistance to extraction, the fossil fuel economy, and commodified property rights. These movements are building a politics of decolonization, respect, solidarity, and hope rather than xenophobia and despair.
\end{abstract}

"The world is in the midst of a change in thinking about economic and social policy in general, and environmental policy in particular. Climate change is showing that the world depends upon a common pool resource, the atmosphere. Other common pool resources, such as fresh water and forests, are also important. Simply put, the world is discovering that people depend upon these common pool resources more than they believed... How should people organize themselves when they depend upon a common pool resource? We need to study examples of peoples who have developed complex and productive systems using a common pool resource as the fundamental source of wealth."

- Ronald L. Trosper, Resilience, Reciprocity and Ecological Economics: Northwest Coast Sustainability (2009:4)

\section{Introduction}

Climate change is an equity challenge. That is to say, it is a life-ordeath challenge to human wisdom as evidenced in socio-political institution-building. ${ }^{1}$

While there are large differences among countries (indicating that policies and institutions do matter), growing economic inequality within many countries since the 1980 s - the same time period when climate change has become entrenched - has allowed a small elite, $1 \%$ of the global population, to become responsible for decisions about $82 \%$ of the world's wealth, including resource extraction, globalized production, investment, and energy production and use (Roser and Ortiz-Ospina, 2016; Oxfam, 2018). Meanwhile global income inequality is very high; half of humanity cannot afford basic food, shelter, education and healthcare (World Health Organization and World Bank, 2017; Roser, 2016). Even within most "emerging" and "rich" countries, a large segment of the population feels disempowered and disrespected, to the point where populist leaders are elected, promising to restore dignity to the masses (Norrlof, 2018; Graves and Valpy, 2018a, 2018b). We are told that "over-consumption" is Anthropocene, inevitable, part of greedy human nature which "we" must struggle to get under control; we are told that sacrifices are necessary. Meanwhile factories close, carbon emissions and regressive taxes rise, economic inequality and insecurity deepen, workers riot in the streets, racism and fascism threaten.

Economic growth nearly always heightens inequities, since in the absence of countervailing policies and institutions, wealth begets more wealth and political power in a positive-feedback cycle. ${ }^{2}$ The tendency under capitalism, state socialism, and colonialism for the powerful to keep coming out better off, and for exploitation of less-powerful people and of nature to accelerate, is the prime driver of climate change (Klein, 2014; Douthwaite, 1999; Korten, 2006; Latouche, 2003; Latouche, 2012; Wu, 2018; Whyte, 2018a). There are not enough negative feedbacks on this tendency of centralized colonial economies to keep

\footnotetext{
E-mail address: esperk@yorku.ca.

${ }^{1}$ As Ostrom stated in her 2009 Nobel Economics lecture, "A core goal of public policy should be to facilitate the development of institutions that bring out the best in humans."

${ }^{2}$ This doesn't necessarily imply that degrowth on the contrary reduces inequities.
} 
growing, at the expense of "nature," Indigenous land sovereignty, and marginalized people, for them to be either socially, politically, or ecologically sustainable (see Thesis 2 in the Introduction to this issue). ${ }^{3}$

However, ecological destruction is not required by human nature quite the contrary. There are many examples of human societies which have lived within ecosystem relationships for thousands of years. Common-pool resources, and other types of commons, ${ }^{4}$ have sustained human economies throughout human history. Collective governance systems that prevent privatization and thus maintain livelihoods for entire communities are increasingly recognized by climate justice activists and scholars as key to equitably meeting the challenges of climate change. Indigenous scholars and activists critique private property in the context of settler colonialism, describing social-political-economic systems with sophisticated forms of property rights that have maintained human societies for thousands of years in a variety of environments (Trosper, 2009; Borrows, 2010). Governance institutions which are central in these systems include those protecting reciprocal ecological relationships that foster collective continuance (Whyte, 2018b), contingent proprietorship and leadership (Trosper, 2009), ceremonial sharing, and social reciprocity demonstrated through potlatches and other rituals (Trosper, 2009; Atleo, 2011). While they have survived, all of these collective governance institutions have been threatened and nearly destroyed by colonialism.

Ecofeminist theorists describe how the rise of capitalism and colonialism led to destruction of previously-existing commons, undermined women's rights, and produced widespread social inequity and marginalization (Federici, 2014, 2018; Mies, 1986/1999; Mies and BennholdtThomsen, 2001). These global and local histories underlie economic, environmental and climate injustice today. In the context of climate change, through a wide range of movements and initiatives - many led by Indigenous people and/or by women - they are beginning to be acknowledged and redressed.

This paper's argument is that equity, decolonization, and activism are central to building political institutions to reduce carbon emissions and material throughput in human economies, so that humans can again flourish within reciprocal relationships with the rest of life. Climate justice is not only important in its own right, for moral/ethical reasons, but is also key to the politics of addressing climate change.

The degrowth movement, which provides a catalyst for activism because it highlights the problems of and solutions to material throughput and over-consumption in rich countries, sometimes underemphasizes equity and the unfair impacts of shrinking GDP on particular people and geographic areas. However, with equity foremost,

\footnotetext{
${ }^{3}$ In traditional justice terminology, climate justice involves the principles of distributional and procedural justice (fairness in how material goods are distributed among people, and in political access by all people), as well as intergenerational justice (meaning that current human consumption doesn't endanger the welfare of future generations). Carrying equity principles a bit further requires including interspecies justice (human respect for other species' welfare and continued existence/non-extinction) and intersectional justice (measures to counteract multifaceted vulnerability and marginalization). Restorative justice implies reshaping human institutions not only for redress but also so that society can self-correct, reinvigorate itself, and prevent inequitable outcomes from occurring. Distributional justice involves material equity; all the other types of justice mentioned above go beyond the material to extend equity principles into dynamic realms of governance, time, race, class, gender and more-than-human species (see Thesis 1 and Thesis 3 in the Introduction to this Special Issue).

${ }^{4}$ Following Turner and Brownhill (2001), in this paper the word 'commons' means organized ways of providing the essentials of life to all. Examples include language, health care, regulated clean air and water, universal education, open environmental spaces and forests, nutritious food, adequate shelter, and equitable political governance. Charlotte Hess, another commons researcher, uses this definition: "A commons is a resource shared by a group where the resource is vulnerable to enclosure, overuse and social dilemmas. Unlike a public good, it requires management and protection in order to sustain it" (Hess, 2008:37).
}

degrowth helps to redefine activist goals, because as (re)commoning takes place, growth itself is less relevant than provisioning - which happens both within and outside of the measured/recognized market, economy, and governance structures (Dengler and Seebacher, 2018). Degrowth thus helps blur old categories and ideals, and focus on new, more relevant ones in times of climate crisis.

The sections of this paper, which take up each of these points, are meant as an overview and entry point into huge literatures on all of the issues mentioned. Following a section on ecofeminism, commons, climate justice, and degrowth, in the next section Indigenous leadership and literatures on climate justice and commons are discussed briefly. The conclusion returns to the political role of equity in addressing climate change, and to the synergies between ecofeminist and Indigenous analyses.

\section{Ecofeminism, commons, climate justice, and degrowth}

The call of ecofeminists ${ }^{5}$ for recognition of collective, unpaid, takenfor-granted foundational contributions of "nature" and "women's work" to socio-economic processes, and the patriarchal exploitation involved, highlights the importance of redistribution and common, shared provisioning in human societies (Mellor, 1997a; Mies, 1986/1999; Salleh, 2009).

As Carol Rose pointed out decades ago, commons of many kinds are 'hidden in plain sight.' Commons such as oceans and watersheds, the Earth's atmosphere, the internet, and languages, are ubiquitous (Hess, 2008); they remain foundational supports for societies and economies, just like unpaid work and 'nature;' and they also act as flywheels, maintaining and undergirding otherwise-unsustainable economic systems. Unpaid work and the vital economic role of ecological systems are all much larger than the economy that non-Indigenous people have learned to 'see' (Gibson-Graham, 2006; Williams, 2005; Fournier, 2013, UNDP, 2015).

The 'first enclosure' of the commons in 16th-century Europe and its colonies was fundamental to both the establishment of capitalism and the deepening of patriarchy (Federici, 2014:68-75). Women, who "suffered most when the land was lost and the village community fell apart" (Ibid. 73), actively fought to protect the commons; "women holding pitchforks and scythes resisted the fencing of the land or the draining of the fens when their livelihood was threatened" (Ibid.). The European enclosures led to social crisis, misogyny and violence against women, reducing their employment options and confining them to the home and unpaid reproductive work. In this transition from feudalism to capitalism, "women suffered a unique process of social degradation that was fundamental to the accumulation of capital and has remained so ever since" (Ibid. 75). Meanwhile, in the colonies, where European conquests imposed the same exploitative systems, women's resistance to enclosures preserved traditional commons-based religions and cultural practices. In Latin America, women "directed or counseled all the great anti-colonial revolts" (Ibid., 232, quoting De Leon, 1985, vol. 1:76).

Commons are still more prevalent and more important in assuring people's livelihoods globally than many may realize. "Worldwide the International Land Alliance estimates that there are an estimated 2 billion people whose lives revolve around subsistence commons of forest, fisheries, arable land, water and wild game" (Bollier and Weston, 2014:1). Those dependent on commons are often the most marginalized. Mutual aid, utopian communities, and grassroots collaborative economic initiatives have allowed Black Americans to persevere in

\footnotetext{
${ }^{5}$ There are many variants of ecofeminism, but all critique the undervaluation and exploitation of women and nature (Plumwood, 1993; Warren, 2000; Gaard and Gruen, 1993, Gaard, 2011, Merchant, 1980, Mellor, 1997a; Salleh, 1997; Mies and Shiva, 2014). Feminist theory in general emphasizes justice, respect for diversity and pluralism, critiques of power and wealth concentration, and the central importance of biological/ecological processes (Spencer et al., 2018).
} 
"finding alternative economic strategies to promote economic stability and economic independence in the face of fierce competition, racial discrimination, and White supremacist violence and sabotage" while building leadership and community stability (Gordon Nembhard, 2014:27).

Institutional economists such as Douglass North "have long contended that property rights lie at the core of the economic growth that has dominated the last 300 years of world history" (Evans, 2005:86), which is to say that the 'first enclosure' of the commons made possible the exponential growth of agrarian and then industrial capitalist economies. The gendered marginalization and misery noted above was a direct result of the economic growth which depended on commodifying and privatizing formerly-communal land. But as long ago as the fourth century BC, "state-defined property was individual, male, and private - a relation which individuals held with the State, not with each other. Collective or communal tenure was, in contrast, described by Plato as 'natural;' its relations were controlled by, and internal to, a selfdefining community.... By the 20th century... (w)hether ideology was communist, socialist, nationalist, or capitalist, a dominant shared strategy... was that community-based tenure (or customary tenure as usually known) must be extinguished in the interests of progress" (Wily, 2018:2).

Traditional common-pool resources and common property have a formal or informal system of property rights, and enforced governance that effectively allows those with shared access to protect the commons from outsiders. Common property allocates certain rights to members of a group: access, extraction, management, exclusion, and/or alienation rights (Hess, 2008:34). "New commons" include a wide range of types of connections between groups of humans and natural resources, goods, property, or cultural assets: "The new commons literature focuses on collective action, voluntary associations, and collaboration. While property rights and the nature of the good may still be important, there is a growing emphasis on questions of governance, participatory processes, and trust; and there is a groundswell of interest in shared values and moral responsibility" (Hess, 2008:37). Even traditional commons such as communally-held land are surprisingly resilient, widespread, and growing in places - due in some cases to the progress of Indigenous peoples in gaining recognition for their communal land rights (Wily, 2018). Neoclassical economists have begun to investigate the reasons why communal tenure can be more efficient than private property: "When the output produced with the asset is a public good, then communal property rights (joint ownership) may sometimes be optimal" (Besley and Ghatak, 2010:4552).

In the face of climate change, movements in the Global South and North, largely led by women, are resisting ongoing enclosures for extraction and fossil fuel industries and, in the process, reclaiming commons. "To the extent that the capitalist energy system is seized and redirected towards commoning, actors within it have reduced dangerous emissions and elaborated an alternative system premised on sustainable energy.... This 'actually existing' movement of commoners is the result of the exploited taking over some of the organizations of capital and using them to (a) undermine profit and at the same time (b) negotiate and construct means for satisfying universal needs" (Brownhill and Turner, 2008:16; see also Akbulut, 2017).

For example, La Via Campesina's Declaration at the 2015 International Forum for Agroecology stated, "Collective rights and access to the commons are a fundamental pillar of agroecology. We share access to territories that are the home to many different peer groups, and we have sophisticated customary systems for regulating access and avoiding conflicts that we want to preserve and to strengthen" (Giacomini, 2016:98). La Via Campesina also notes, "As savers of seed and living libraries of knowledge about local biodiversity and food systems, women are often more closely connected to the commons than men" (Ibid).

Necessary steps in the process of re-commoning include "defending and reclaiming of public space, and opposition to further privatization of common resources and spaces; ... (localized) production, exchange, and consumption; ... decentralization; reciprocity (instead of) mechanical mass solidarity; ... policy from below, as a living process, instead of policy from above; ... (and) manifold ways of realizing a community and a multiplicity of communities" (Mies and BennholdtThomsen, 2001:1021-1022).

In principle, degrowth and commoning movements seem like natural allies. They arise in opposition to crushing centralization and globalization, income and power concentration, and destruction of local communities; they are fundamentally democratic and relationshipbased; their stance is critical of "sustainable development," counterhegemonic, and anti-capitalist. But in my view, topics such as women, gender, intersectionality, Indigenous peoples, colonialism, and implications for the marginalized remain underexplored in degrowth analysis (Deschner and Hurst, 2018). There are exceptions, and a few authors call for venues or discussions or shared political platforms to bring together different perspectives (e.g. Martinez-Alier et al., 2010:1746, Martinez-Alier, 2012; Bonaiuti, 2012; Asara et al., 2015). (Re)commoning opens an ethical, political, and currently relevant means to motivate and cushion degrowth, broaden its appeal, and emphasize its practical/livelihood applications, in recognition of the tremendous potential that degrowth has to negatively affect marginalized people whose precarious lifeways imply minimal ability to handle shocks and disruption (D'Alisa et al., 2014).

What steps might this entail? The degrowth movement has not (yet?) seriously considered or addressed the long-standing feminist and ecofeminist literatures regarding the extent to which the measured/ growth economy depends upon unpaid work, mostly done by women, and unpaid ecological services. Many degrowth authors seem blind to the effects of patriarchy, gender violence, colonialism, and wage discrimination in forcing certain members of humanity, and "nature" (c.f. Francis Bacon - see Merchant, 2008), to continue providing other members of humanity the means to support their well-being.

Degrowth theorist Takis Fotopoulos points out that degrowth addresses the ecological crisis while essentially ignoring the political, social, economic, and class crises (Fotopoulos, 2007:5). This is a problem, he says: "The crucial issue today is how we may create a new society where institutionalized domination of human being over human being and the consequent idea of dominating nature are ruled out" (2007:8). Fotopoulos shows how both socialist and capitalist growth depend fundamentally on income concentration - both materially and environmentally - since industrialization depends on privatization of the means of production and division of labour; it is simply not possible for the benefits of increased production to be universalized because this would endanger the conditions of income disparity required by profit maximization. "Progress, in the sense of improvements in welfare through economic growth, has a necessarily non-universal character. Therefore, the moment of truth for the present social system will come, when it will be universally acknowledged that the very existence of the present wasteful consumption standards depends on the fact that only a small proportion of the world population, now or in the future, are able to enjoy them" (2007:14-15). He thus provides the reason why degrowth cannot prioritize redistribution OR gender equity without what he calls a "cultural revolution," the "transformation of existing institutions" - but this must be accomplished without alienating "the lower social groups (including the lower middle class), which would particularly have to pay the price for the adoption of the measures involved" if they are carried out within the market system by internalizing externalities (2007: 18).

"Progress," as Maria Mies noted in 1986, depends not just on global income inequality but on patriarchy, and on disguising women's economic interests even from themselves. For society to vote democratically for degrowth, these fundamental characteristics of prevailing economic systems would need to be maintained. Fotopoulos hints at the extensive changes which would be necessary to bring this exploitation to light when he says, "To my mind, it is only through a transitional 
strategy aiming to create new democratic political and economic institutions and, through paideia, which would aim to make hegemonic the corresponding values, that we could realistically hope to create the conditions for the emergence of an economy and society not based on economic growth: a real ecological democracy, as an integral part of an Inclusive Democracy" (2007:19). The word paideia, meaning "childrearing and education," gives away the deep ecofeminist content of his remarks: child-rearing and education, currently taken for granted, not worthy of comment, and done largely for free almost exclusively by women, are the key to transforming society so that people can generally see that growth is not the point; ongoing livelihood and quality of life for all is.

What will induce the emergent "new forms of economic and social organization" (Bonaiuti, 2012) to be good from an ecofeminist perspective - that is, equitable for women and all marginalized 'others', and for more-than-human life/"nature"? The answer to this question is the crux of climate-crisis-driven system change.

From the standpoint of equity/redistribution and ecological balance, degrowth thus can seem a rather tangential tactic. Because some degrowth theorists focus mainly on reducing humans' energy use and material throughput, the degrowth movement they envision can seem somewhat conflicted and unclear about its equity implications. Degrowth activists generally maintain that they want degrowth with equity, but the movement itself to date largely lacks participation and input from marginalized workers from either the global North or the global South, who might be able to represent and integrate those concerns - if indeed this is possible (see Thesis 4 in the Introduction to this issue). Other degrowth proponents define their goals in terms of reorganizing the social metabolism towards socially-determined aims, once growth itself is decentred as a societal indicator of progress (Kallis and March, 2014).

Turner et al., 2012 article in a special issue of Capitalism Nature Socialism on degrowth, substitute 'de-alienation' in Marxian terms as a better focus than degrowth, since this incorporates both justice AND ecology. Justice, because all workers share the alienation which flows from over-consumption and overwork, and this shared burden provides a basis for political action, and for economic restructuring with equity. Ecology, because commons are an age-old solution evolved by humans to meet the challenges of joint sustenance, risk, and long-term environmental equilibrium.

In terms of social justice, given the ever-present reality that economic contraction (or changes of any kind) tend to impact most gravely on people who are already marginalized, most degrowth theorists specify that attention to justice is crucial in bringing about degrowth, and they try to include voices from the margins in arguing for the degrowth agenda. Part of this strategy includes pointing out that growth too hurts the poor, due to its ecological, climate change, and neoliberal social impacts. Martinez-Alier, a central figure in the degrowth movement, argues in his book The Environmentalism of the Poor (2002) that strategies used by poor people worldwide to minimize or buffer the environmental consequences of economic growth, which fall heavily on them and endanger their more sustainable livelihoods, effectively shrink the size of the measured, growth-focused economy.

Nonetheless, from an ecofeminist and equity-driven perspective, it seems dangerous to advocate degrowth without very clear and specific corollary measures to negate the tendency of the powerful to come out better-off.

Traditional income redistribution mechanisms usually rely at least theoretically on growth, so that the least well-off can gradually be allocated a proportionally larger share of economic returns without others having to receive absolutely less. In practice, growth is usually accompanied by increases in both economic and political inequity, and worsening income distribution (Piketty, 2014; Wilkinson and Pickett, 2009). But what mechanism can address historically-based material inequities, both within and among countries and regions, as well as globally? Without growth as the engine, in reality as well as in theory, what can drive progressive North-South redistribution? Economic localization and decentralization can lead to greater equity in specific cases (Kaufman, 2012; Gibson-Graham, 2006; Rowan, 2019) but the post-colonial/decolonizing global distribution questions remain (Dengler and Seebacher, 2018, 2019; Lang, 2017; Paulsen, 2017). This remains an under-developed area of degrowth theory.

Since degrowth involves substituting social benefits which are not derived from material throughput in the economy for economic benefits which are materially-dependent, it is centrally concerned with issues like unpaid work, caring, community as differentiated from individual welfare, and other such matters which feminist economists have studied for decades. Ecofeminists, in particular, have long considered these issues (Mellor, 1997b, Mellor, 1992, Kuiper and Perkins, 2005, Shiva, 1988, Mies and Shiva and Mies, 1993).

Undervalued economic factors include women's work (and indeed all under- and unpaid work), as well as non-monetized services and material inputs from 'nature' and colonial theft which are incorporated into the economic sphere virtually for free. Whenever they are estimated - e.g. Costanza et al. (1997, 2014), Pietilä (1997); D'Alisa and Cattaneo (2013); UNDP (2015) - these unpaid or 'free' services and goods generally dwarf the measured economy in value, yet they are usually not central to policy deliberations and they are often ignored entirely. Women's work and "nature" are crucial and irreplaceable foundations of the measured economy. Maria Mies has shown how capitalism was founded and continues to depend for its existence on the unpaid and underpaid work of women; Mary Mellor and Ariel Salleh and many other theorists have traced the material links between women's work and what economists call "ecosystem services"; these issues of underpayment and inequality based in social injustice and environmental depredation, and the predictable ways in which they create economic winners and losers, are grounded in colonialism, patriarchy, under-development, and race and class discrimination both within countries and globally.

Just as the 'jobs vs. environment' conflicts of 20 years ago are being superseded via 'green jobs' and 'green community development' movements which recognize the importance of safe green sustainable jobs for all workers, as the climate crisis intensifies 'degrowth vs. redistribution' conflicts will need to be overcome through 'de-alienation via commoning,' which lays the groundwork for all members of society to be supported, simply, first and foremost, so that growth becomes irrelevant (Macgregor, 2014).

This focus on participatory commons governance decenters both growth and degrowth as goals: Degrowth is mostly a means to an end, which is a just, peaceful quality of life for all. In comparison with current realities, income redistribution is more central than degrowth per se as a step in a good direction. More progressive wealth taxation policy including inheritance taxes and ceilings that favour wealth distribution; crackdowns on tax havens and tax flight; and anti-corruption policies in general are examples of ways to advocate and move towards this goal even within capitalism and current political structures, by building political will for transparency and redistribution. More fundamental reconstruction of commons in the Western/European dominated world, however, will involve deep restructuring of economic systems, livelihoods, rights, and culture (Fuente Carrasco et al., 2019; Whyte, 2017a, 2017b, 2018a).

Colonialism, as noted above, violently suppressed and continues to undermine Indigenous socio-economic institutions that exemplify commons governance for securing sustainable livelihoods. Is it possible for ecofeminist, degrowth, and Indigenous activists to become allies in re-commoning?

Says Indigenous writer Lindsay Nixon:

"Indigenous feminists know that mainstream feminism predominantly represents white settler feminists who, more often than not, choose to ignore the ongoing processes of colonialism from which they actually benefit.... Ecofeminism that appropriates Indigenous environmental 
knowledges often fails to fully represent what environmental justice means to Indigenous communities. What is often ignored within these analyses is how neocolonial state violence, compounded by exposure to environmental contaminants, is embodied in very specific ways for Indigenous women and Two-Spirit peoples.... Indigenous peoples have again and again described how solutions to the effects of environmental contamination need to extend far beyond the return of land.... If ecofeminists truly want to engage with Indigenous feminism to legitimize their own movements, they must first engage with their own positionality and privilege as settlers: a positionality on which the continuation of settler-colonialism and the ongoing genocide of Indigenous peoples are prefaced. Furthermore, Indigenous peoples don't need saviour feminists defining what strategies must be used to address environmental contamination within Indigenous communities.... What Indigenous feminists want from eco-feminists is simple: Sit down, be quiet, and listen"

(Nixon, 2015)

This call to listen respectfully is consistent with an empirical, evidence-based approach to sustainable livelihoods, as pointed out by Ronald Trosper in the quotation that heads this paper (Trosper, 2009:4).

\section{Indigenous commons, climate justice, and degrowth}

Sustainable ecological practices, communal wealth-sharing, and institutions that preserve long-term quality of life are apparent in many Indigenous governance systems. In Canada and elsewhere, Indigenous leadership, especially by young women, is generating a new impetus for settler-allies to learn about and act on these lifeways and the history and pernicious legacies of colonialism.

International legal scholar Shawkat Alam notes, "Collective rights are often affiliated with Indigenous people, as they are defined as rights held by groups.... However, it has been argued that the 'recognition of collectivities and collective rights is one of the most contested in international law and politics'. Indeed... this concept of collective rights can be seen to conflict with Western ideas of individual freedom and liberty.... Collective rights have been seen to foster tolerance, and diversity of culture and knowledge. To this end, many Indigenous peoples view the recognition of their cultural rights as 'of paramount importance' or 'as a token of respect towards their identity and communities as well as the only way for their survival and development"' (Alam, 2012:588; Xanthaki, 2007:13).

Indigenous legal scholar John Borrows has demonstrated the extent to which First Nations governance traditions have provided a foundation for current Canadian law, as part of a living, resilient legal system which 'works' in the modern world (Borrows, 2010). Carol Rose, in a very thorough 1986 study, demonstrated that the legal status of commons is well-represented, understood and respected in modern Western legal traditions, and in fact that there are so many types and advantages of collective property rights that their benefits remain unambiguous; "the commons was not tragic, but comedic, in the sense of a story with a happy outcome" (Rose, 1986:723).

The Iroquois or Haudenosaunee confederacy among the Seneca, Cayuga, Onondaga, Oneida, Mohawk, and Tuscarora peoples was "probably the greatest Indigenous polity north of the Rio Grande in the two centuries before Columbus and definitely the greatest in the two centuries after" (Mann, 2005:330). The Haudenosaunee 'Great Law of Peace,' with its 117 codicils setting out ways of achieving political balance, requiring subsidiarity, and setting checks on authority, has been cited as the direct inspiration for the U.S. Constitution (Ibid.:333). However, while they adopted Haudenosaunee protections for liberty and individual rights going far beyond European standards of the time, the U.S. constitutional 'framers' failed to incorporate Haudenosaunee traditions of communal property ownership (Ibid.: 333-336). Arguably, they thus missed out on a crucial piece of the overall system's traditional, well-evolved constraints on individual wealth-accumulation and, thus, political power - given the U.S. colonial governance system's lack of negative feedbacks on wealth accumulation, unlike Indigenous governance systems.

Indigenous histories document a diversity of ways of organizing society to prioritize resilience, interdependence, and ecological relationships (Trosper, 2009; Leroy, 2016). Indigenous traditions of hospitality, sharing, potlatch (or giving away material wealth to demonstrate moral and community standing), humility, and reverence for the earth and all its creatures and life systems are central to locallyappropriate commons governance processes. First Nations also had nested governance institutions which seem to correspond with what Elinor Ostrom has cited as successful 'polycentric' ways to govern largescale commons (Ostrom, 2009a, 2010, 2014).

The active suppression of the potlatch by the Canadian government between 1884 and 1951, on penalty of 2 to 6 month jail terms, shows the extent to which gift-giving, generosity, and moral community relationships were inimical to the selfishness and violence of colonial capitalist expansionism. During the potlatch, guests are named and given gifts with the words, "you are recognized." In The Principles of Tsawalk: An Indigenous Approach to Global Crisis, E. Richard Atleo (Umeek) says,

"Over time it was learned that gift giving and recognition promoted balance and harmony between beings, that (this) obeyed what might be called the laws of the positive side of polarity.... When two neighbouring nations shared the same resources, whether cedar, salmon, or human, then it was obvious to the ancient Nuu-chah-nulth that to neglect the act of recognition would open the way to conflict, while to observe the act of recognition, through what I refer to as 'mutual concern,' would open the way to balance and harmony."

(Atleo, 2011, pp. 80-81)

Indigenous forms of resource management prior to colonization included burning forests to create grasslands for common hunting grounds and areas where food plants and medicinal herbs could be harvested by visitors of many nations (First Story, 2016; Frost, 2019; Turner et al., 2000); Shasta and Hupa management of salmon fisheries through a combination of ritual, ceremony, taboos, respect for elders, and astute observation of the fish over many years (Berkes and Folke, 2002:126-127); Cree oral history to transmit knowledge of long-term cycles in caribou herd fluctuations (Ibid.:140); and Nishinaabeg myths and stories to convey knowledge about interrelated natural phenomena, along with human dependence and humility (Simpson, 2011:18). All these practices depend upon shared cultures, resource use by groups for the benefit of the whole collectivity, and limitations not just on individual consumption and wealth accumulation but on overall human consumption when necessary to preserve the natural resource - in other words, effective and sustainable commons governance.

Balanced gender roles and social domains (e.g. Haudenosaunee women were clan heads; they chose the male sachems or chiefs) were and are the norm in many Indigenous societies (Mann, 2005:372-373). Indigenous women, as those responsible for water and life-transmission, lead the most powerful grassroots environmental movements in Canada today (Perkins, 2017; Temper, 2018b). Indigenous chief and activist Arthur Manuel and R.M. Derrickson comment in their book Unsettling Canada: A National Wake-Up Call that women have long held leading roles in Indigenous activism on land, rights and the environment, and the majority of young Indigenous activists today are women (Manuel and Derrickson, 2015:211). Indigenous authors have pointed out that, besides gendered economic and social roles in a patriarchal society, cultural factors also lead Indigenous women to assert their voices and leadership on matters related to water, health, education and livelihoods (Gorecki, 2014; Nixon, 2015; Awadalia et al., 2015; Ellis, 2015; Whyte, 2014a).

The links between exploitation of land, resources, and women are clear: "...Indigenous women activists and academics have shown how the foundation of contemporary capitalism was contingent on industrial 
resource extraction of Indigenous people's land, which was also simultaneously fully reliant on disempowering any positive ethic towards nature and women. This was achieved by installing European forms of gender relations and dismantling women's power, aided by the appropriation of Indigenous women's bodies. Residential schools were perhaps the strongest tools in reinscribing balanced gender relations of North American Indigenous matrilocal societies into the unequal ones of patriarchal models imposed by European colonizers and settlers.... (T)he centrality of resisting the colonization of Mother Earth, Terra Madre, and Pachamama is paramount" (Gorecki, 2014). ${ }^{6}$

As noted by climate justice activists, it is those on the front lines of climate change - both extreme weather events and extraction - who are most aware of its impacts and most knowledgeable about how they should be addressed; this puts women at the forefront of climate justice struggles (Beuchler and Hanson, 2015:228). Indigenous women, facing multiple health and livelihood crises, are leading powerful movements to address this issue at its source (Whyte, 2014a; Whyte, 2017a, 2017b; Green, 2017; Temper, 2018a).

Commoning, or reclaiming/rebuilding Indigenous governance systems, requires decolonization. Dene activist Glen Coulthard, in his book Red Skin White Masks, discusses the hope and the promise of commons:

"What must be recognized by those inclined to advocate a blanket 'return to the commons' as a redistributive counterstrategy to the neoliberal state's new round of enclosures, is that, in liberal settler states such as Canada, the 'commons' not only belong to somebody - the First Peoples of this land - they also deeply inform and sustain Indigenous modes of thought and behaviour that harbour profound insights into the maintenance of relationships within and between human beings and the natural world built on principles of reciprocity, nonexploitation and respectful coexistence. By ignoring or downplaying the injustice of colonial dispossession, critical theory and left political strategy not only risks becoming complicit in the very structures and processes of domination that it ought to oppose, but it also risks overlooking what could prove to be invaluable glimpses into the ethical practices and preconditions required for the construction of a more just and sustainable world order"

(Coulthard, 2014:12)

Justice-oriented economic transformation requires non-Indigenous people to undertake significant and ongoing education about the damage and legacies of colonialism in order to begin to build economic institutions that respect the contributions and rights of women and Indigenous peoples, both individually and collectively (Davis, 2010; Tuck, 2017; Fortier, 2017; Davis and Todd, 2016; Whyte, 2016). Indigenous governance systems underscore how foundational justice is for long-lived and ecologically-sustainable commons. However, degrowth theorists and activists have yet to engage much with this, or with Indigenous activists and approaches in North America; the European degrowth movement even less so.

Global commoning movements grounded in Indigenous lifeways, including Buen Vivir, Pachakuti, and Sumak Kawsay in Latin America, Ecological Swaraj in India, Gross National Happiness in Bhutan, Ubuntu in Africa, and Maori "Economy of Mana" in New Zealand, have many parallels with degrowth, especially their insistence on transformative reorganization of society to recenter harmony among humans and with the more-than-human world, as some degrowth writers point out (Kothari et al., 2014; Garcia, 2012; Gudynas, 2015; Thomson, 2010; Della Valle, 2017; Meynen, 2016; Hoeft, 2018; Martinez-Alier, 2012; Latouche, 2007; Escobar, 2015; Foster, 2011; Verma, 2017).

\footnotetext{
${ }^{6}$ Canada's ongoing crisis of more than 1200 Missing and Murdered Indigenous Women and Girls since 1980 shows that the deadly connections among capitalism, colonialism, resource extraction, ecological destruction, patriarchy, gendered violence, and racism continue (Kirkup, 2016; InterAmerican Commission on Human Rights, 2014; Narine, 2015; Women's Earth Alliance and Native Youth Sexual Health Network, 2016; Green, 2017).
}

\section{Conclusion: equity, commons, and climate justice}

Women's movements, and especially Indigenous women's movements, revive and underscore the importance of participatory democracy and local responsibility for preventing the commodification of water, mineral resources, forests, fisheries, information, collective transportation, and other widely shared systems that are vitally important for most communities' livelihoods and for human flourishing (Bollier and Weston, 2013; Murota and Takeshita, 2013; Shimada, 2010; Dyer-Witheford, 2011; Cochrane, 2014; Hess and Ostrom, 2007; Great Lakes Commons, 2013).

The toxic effects of fossil fuel and other extraction, and industrial production more generally - water and air pollution, ecosystem impacts on fish, wildlife, soils, agriculture, etc., trampling on local governance processes, Indigenous land rights, and the health of the most vulnerable - first and most clearly demonstrate the deathly problematic nature of the economic system that produces climate change. The impacts of fossil fuel consumption - greenhouse gas emissions leading to extreme weather events, weather variability, etc. - while global in their implications, are longer-incubating but also crucially important in perpetuating climate change. In both production and consumption, roles and impacts are gendered (Cohen, 2017) and environmental injustices abound. Climate justice includes both production and consumption related activism.

This paper presents an alternative, deeper argument regarding a way forward in times of worsening inequality and climate chaos: that humans have proven themselves to be capable of building socio-cultural systems which secure a respected place for all members of society and provide for their livelihoods, material needs and emotional welfare through commons, protected by collective social governance institutions. Despite centuries of colonialism, imperialism, and capitalist growth, such commons continue to sustain and supplement the livelihoods of most people in the world. Led by the marginalized, who are well aware of this, commoning is a mode of social activism which allows people to relink with the means to collectively control production themselves, outside of the market and independent of capital (Fournier, 2013).

Commoning implies addressing all forms of justice: distributional, procedural, intergenerational, intersectional, interspecies, restorative. It also requires understanding the deep colonial roots of growth itself, in order to actively "unsettle" the collaborative process of redressing wrongs, building respect and humility, and envisioning a resilient, sustainable future. Relationships between settler ecofeminists, Indigenous women activists, and global climate justice movements require settlers to commit to ongoing self-education, respect, and solidarity in working towards decolonization.

Equity-oriented degrowth, climate justice, and commoning are thus potentially mutually reinforcing, and offer a politically viable path towards energy transition and a post-capitalist future. The first step along this path is to dismantle colonialism, restore stolen land to its Indigenous caretakers in reconciliation, and (re)build the social respect, relationships and fundamental human values that can link all members of society together, without fear or xenophobia, for shared and responsible commons governance.

\section{References}

Akbulut, B., 2017. Carework as Commons: Toward a Feminist Degrowth Agenda. Resilience (February 2). http://www.resilience.org/stories/2017-02-02/careworkas-commons-towards-a-feminist-degrowth-agenda/.

Alam, S., 2012. Collective indigenous rights and the environment. In: Alam, S., Bhuiyan, J.H., Chowdhury, T.M., Techera, E.J. (Eds.), Routledge Handbook of International Environmental Law. Routledge, New York, pp. 585-602.

Asara, V., Otero, I., Demaria, F., Corbera, Ed, 2015. Socially sustainable edgrowth as a social-ecological transformation: repoliticizing sustainability. Sustain. Sci. 10 (3), $375-384$.

Atleo, E.R. (Emeek), 2011. Principles of Tsawalk: An Indigenous Approach to Global Crisis. UBC Press, Vancouver. 
Awadalia, C., Coutinho-Sledge, P., Criscitiello, A., Gorecki, J., Sapra, S., 2015. Climate Change and Feminist Environmentalisms: Closing Remarks. FeministWire (May 1). http://www.thefeministwire.com/2015/05/climate-change-and-feministenvironmentalisms-closing-remarks/.

Berkes, F., Folke, C., 2002. Back to the future: ecosystem dynamics and local knowledge. In: Gunderson, L.H., Holling, C.S. (Eds.), Panarchy: Understanding Transformations in Human and Natural Systems. Island Press, Washington, DC/Covelo, CA/London, UK, pp. 121-146.

Besley, T., Ghatak, M., 2010. Property rights and economic development. In: Rodrik, D., Rosenzweig, M. (Eds.), Handbook of Development Economics. vol. 5. pp. 4535-4595. ch. 68. http://eprints.1se.ac.uk/25428/1/property_rights_and economic_development.pdf.

Beuchler, S., Hanson, A., 2015. A Political Ecology of Women, Water, and Global Environmental Change. Routledge, New York/London.

Bollier, D., Weston, B., 2013. Green Governance: Ecological Survival, Human Rights, and the Law of the Commons. Cambridge University Press, Cambridge.

Bollier, D., Weston, B., 2014. The Commons as a Growing Global Movement. CSRwire Talkback (Jan. 31). http://www.csrwire.com/blog/posts/1203-the-commons-as-agrowing-global-movement.

Bonaiuti, M., 2012. Degrowth: tools for a complex analysis of the multidimensional crisis. Capital. Nat. Social. 23 (1), 30-50.

Borrows, J., 2010. Canada's Indigenous Constitution. University of Toronto Press, Toronto.

Brownhill, L., Turner, T., 2008. Commoners against Climate Change. Europe Solidaire sans Frontières. http://www.europe-solidaire.org/spip.php?article9416.

Cochrane, Regina, 2014. Climate change, Buen Vivir, and the dialectic of enlightenment: toward a feminist critical philosophy of climate justice. Hypatia 29 (3), 577-598.

Cohen, M.G., 2017. Climate Change and Gender in Rich Countries: Work, Public Policy and Action. Routledge, London/New York.

Costanza, R., et al., 1997. The value of the world's ecosystem services and natural capital. Nature 387, 253-260.

Costanza, R., de Groot, R., Sutton, P., van der Ploeg, S., Anderson, S.J., Kubiszewski, I., Farber, S., Turner, R.K., 2014. Changes in the global value of ecosystem services. Glob. Environ. Chang. 26, 152-158.

Coulthard, G.S., 2014. Red Skin White Masks: Rejecting the Colonial Politics of Recognition. University of Minnesota Press, Minneapolis.

D'Alisa, G., Cattaneo, C., 2013. Household work and energy consumption: a degrowth perspective. Catalonia's case study. J. Clean. Prod. 38, 71-79.

D'Alisa, G., Demaria, F., Kallis, G., 2014. Degrowth: A Vocabulary for a New Era. Routledge, London/New York.

Davis, L. (Ed.), 2010. Alliances: Re/Envisioning Indigenous-non-Indigenous Relationships. University of Toronto Press, Toronto.

Davis, H., Todd, Z., 2016. On the importance of a date, or decolonizing the Anthropocene. ACME Int. J. Crit. Geogr. 16 (4), 761-780.

De Leon, A.G., 1985. Resistencia y Utopia. vols. 1 and 2 Ediciones Era, México, DF.

Della Valle, P., 2017. Indigenous degrowth and global capitalism: exploring notions of development in New Zealand literature. In: Ramsey-Kurtz, H., Kennedy, M. (Eds.), Uncommon Wealths in Postcolonial Fiction. Brill, Leiden, pp. 207-225.

Dengler, C., Seebacher, L.M., 2018. Growth Pessimism, but Degrowth Optimism. Social Europe (17 December). https://www.socialeurope.eu/growth-pessimism-butdegrowth-optimism.

Dengler, C., Seebacher, L.M., 2019. What about the global south? Proposal for a feminist decolonial degrowth approach. Ecol. Econ (in this issue).

Deschner, C., Hurst, E., 2018. Decolonisation and Degrowth. Degrowth blog (February 1). https://www degrowth.info/en/2018/02/decolonisation-and-degrowth/.

Douthwaite, R., 1999. The Growth Illusion. Lilliput Press, Dublin.

Dyer-Witheford, N., 2011. Nintendo capitalism: enclosures and insurgencies, virtual and terrestrial. Can. J. Dev. Stud. 22 (4), 965-996.

Ellis, C., 2015. Solidarity for Feminist Climate Justice. Feminist Wire (April 27). http:// www.thefeministwire.com/2015/04/solidarity-for-feminist-climate-justice/.

Escobar, A., 2015. Degrowth, post-development, and transitions: a preliminary conversation. Sustain. Sci. 10 (3), 451-462.

Evans, P., 2005. The new commons vs. the second enclosure movement: comments on an emerging agenda for development research. Stud. Comp. Int. Dev. 40 (2), 85-94.

Federici, S., 2014. Caliban and the Witch: Women, the Body, and Primitive Accumulation. Autonomedia, Brooklyn, NY.

Federici, S., 2018. Re-Enchanting the World: Feminism and the Politics of the Commons. Kairos/PM Press, Oakland, CA.

First Story, 2016. Black Oak Savannah. https://www.highparknature.org/wiki/wiki.php? $\mathrm{n}=$ History.IndigenousHistory.

Fortier, C., 2017. Unsettling the Commons: Social Movements Within, Against, and Beyond Settler Colonialism. Arbeiter Ring Publications, Winnipeg.

Foster, J.B., 2011. Capitalism and degrowth: an impossibility theorem. Mon. Rev. 62, 8. https://monthlyreview.org/2011/01/01/capitalism-and-degrowth-an-impossibilitytheorem/.

Fotopoulos, T., 2007. Is degrowth compatible with a market economy? Int. J. Incl. Democr. 3 (1), 1-16.

Fournier, V., 2013. Commoning: on the social organization of the commons. Management 16, 433-453. https://www.cairn.info/revue-management-2013-4-page-433.htm.

Frost, K., 2019. First nations sovereignty, environmental justice, and degrowth in British Columbia, Canada. Ecol. Econ (in this issue).

Fuente Carrasco, M.E., Barkin, D., Hernández Mecinas, E., Tapia, R.C., Mendoza Díaz, M.M., 2019. Governance from below and environmental justice: community water management from the perspective of social metabolism. Ecol. Econ (in this issue).

Gaard, G., 2011. Ecofeminism revisited: rejecting essentialism and replacing species in a material feminist environmentalism. Fem. Form. 23 (2), 26-53.
Gaard, G., Gruen, L., 1993. Ecofeminism: toward global justice and planetary health. Soc. Nat. 2, 1-35.

Garcia, E., 2012. Degrowth and buen vivir (living well): a critical comparison. In: Presented at the 3rd International Conference on Degrowth, Venice, September 19-23, . https://www.degrowth.info/wp-content/uploads/2017/01/WS_20_FP GARCIA.pdf.

Giacomini, T., 2016. Ecofeminism and system change: women on the frontlines of the struggle against fossil capitalism and for the solar commons. Can. Woman Stud. 31 (1-2), 95-101.

Gibson-Graham, J.K., 2006. A Post-Capitalist Politics. University of Minnesota Press, Minneapolis, MN.

Gordon Nembhard, J., 2014. Collective Courage: A History of African American Cooperative Economic Thought and Practice. Pennsylvania State University Press, University Park, PA.

Gorecki, J., 2014. 'No Climate Justice Without Gender Justice': Women at the Forefront of the People's Climate March. The Feminist Wire (September 29). http://www. thefeministwire.com/2014/09/climate-justice-without-gender-justice-womenforefront-peoples-climate-march/.

Graves, F., Valpy, M., 2018a. Ford's Win Exposes the Angry Blind Spot of Canadian Democracy. The Globe and Mail (June 8). https://www.theglobeandmail.com/ opinion/article-fords-win-exposes-the-angry-blind-spot-of-canadian-democracy/.

Graves, Frank, Valpy, Michael, 2018b. Canada is a tinderbox for populism. In: The 2019 Election Could Spark it. Macleans (December 3). https://www.macleans.ca/politics/ canada-is-a-tinderbox-for-populism-the-2019-election-could-spark-it/?utm medium $=$ organic\&utm_source $=$ Facebook\&fbclid $=$ IwAR2eR8wEwAOQbCMcs5f8CQ51RjGSaNcJYZOQPA7D9xCE4t9NepknkI2rdeQ.

Great Lakes Commons, 2013. http://greatlakescommonsmap.org/main.

Green, Joyce, 2017. Making Space for Indigenous Feminism, 2nd ed. Fernwood Publishing, Halifax/Winnipeg.

Gudynas, E., 2015. Buen Vivir. In: D'Alisa, G., Demaria, F., Kallis, G. (Eds.), Degrowth a Vocabulary for a New Era. Routledge, London/New York, pp. 201-204.

Hess, C., 2008. Mapping the New Commons. Syracuse University Library, Syracuse, NY. https://papers.ssm.com/sol3/papers.cfm?abstract_id = 1356835 .

Hess, C., Ostrom, E., 2007. Understanding Knowledge as Commons: From Theory to Practice. MIT Press, Cambridge, MA.

Hoeft, T., 2018. Towards the Pluriverse: How to Connect Degrowth and Ubuntu. In: Lund University Thesis HEKM51 20181, . https://lup.lub.lu.se/student-papers/search/ publication/8945696.

Inter-American Commission on Human Rights, 2014. Missing and Murdered Indigenous Women in British Columbia, Canada. Organization of American States, Washington, DC. http://www.oas.org/en/iachr/reports/pdfs/indigenous-women-bc-canada-en. pdf.

Kallis, G., March, H., 2014. Imaginaries of hope: the utopianism of degrowth. Ann. Assoc. Am. Geogr. 105 (2), 360-368.

Kaufman, C., 2012. Getting Past Capitalism: History, Vision, Hope. Lexington Books, Lanham, MD.

Kirkup, K., 2016. Carolyn Bennett Says There Are More than 1,200 Missing or Murdered Indigenous Women. Huffington Post (16 February).

Klein, N., 2014. This Changes Everything: Capitalism vs. the Climate. Simon and Schuster, New York.

Korten, D., 2006. The Great Turning: From Empire to Earth Community. Berrett-Koehler Publishers, Oakland, CA.

Kothari, A., Demaria, F., Acosta, A., 2014. Buen Vivir, degrowth and ecological Swaraj: alternatives to sustainable development and the green economy. Development 57 (3-4), 362-375.

Kuiper, E., Perkins, E., 2005. Introduction: exploring feminist ecological economics. Fem. Econ. 11 (3), 107-108.

Lang, M., 2017. Degrowth: Unsuited for the Global South? Alternautas blog. http://www. alternautas.net/blog/2017/7/17/degrowth-unsuited-for-the-global-south.

Latouche, S., 2003. Would the West Actually Be Happier With Less? The World Downscaled. Le Monde Diplomatique (December 12, 2003).

Latouche, S., 2007. Degrowth Economics. Le Monde Diplomatique (July 3, 2007).

Latouche, S., 2012. Can the left escape economism? Capital. Nat. Social. 23 (1), 74-78.

Leroy, J.P., 2016. Mercado ou Bens Comuns? O papel dos povos indígenas, comunidades tradicionais e setores do campesinato diante da crise ambiental. FASE, Rio de Janeiro. http://fase.org.br/wp-content/uploads/2016/10/FASE Mercado-ou-Bens-ComunsJPL-PDF.pdf.

Macgregor, S., 2014. Only resist: feminist ecological citizenship and the post-politics of climate change. Hypatia 29 (3), 617-633.

Mann, C.C., 2005. 1491: New Revelations of the Americas Before Columbus. Alfred A. Knopf, New York.

Manuel, A., Derrickson, R.M., 2015. Unsettling Canada: A National Wake-Up Call. Between the Lines, Toronto.

Martinez-Alier, J., 2012. Environmental justice and economic degrowth: an alliance between two movements. Capital. Nat. Social. 23 (1), 51-73.

Martinez-Alier, J., Pascual, U., Vivien, F., Zaccai, E., 2010. Sustainable de-growth: mapping the context, criticisms and future prospects of an emergent paradigm. Ecol. Econ. 69, 1741-1747.

Mellor, M., 1992. Breaking the Boundaries: Towards a Feminist Green Socialism. Virago Press, London.

Mellor, M., 1997a. Feminism and Ecology. NYU Press, New York.

Mellor, M., 1997b. Feminism and Ecology. Polity Press, Cambridge, UK.

Merchant, C., 1980. The Death of Nature: Women, Ecology and the Scientific Revolution.

Merchant, C., 2008. 'The violence of impediments': Francis Bacon and the origins of experimentation. Isis 99, 731-760.

Meynen, N., 2016. Why the Degrowth Debate Is Growing. Ejolt blog (September 5). 
http://www.ejolt.org/2016/09/degrowth-debate-growing/.

Mies, M., 1986/1999. Patriarchy and Accumulation on a World Scale: Women in the International Division of Labour. Zed Books, London.

Mies, M., Bennholdt-Thomsen, V., 2001. Defending, reclaiming and reinventing the commons. Can. J. Dev. Stud. 22 (4), 998-1023.

Mies, M., Shiva, V. (Eds.), 2014. Ecofeminism, 2nd ed. Zed Books, London.

Murota, T., Takeshita, K., 2013. Local Commons and Democratic Environmental Governance. United Nations University Press, Tokyo/New York/Paris.

Narine, S., 2015. Violence against aboriginal women not an aboriginal-only issue. Windspeaker 23 (1). http://www.ammsa.com/publications/alberta-sweetgrass/ violence-against-aboriginal-women-not-aboriginal-only-issue.

Nixon, L., 2015. Ecofeminist Appropriations of Indigenous Feminisms and Environmental Violence. Feminist Wire (April 30). http://www.thefeministwire.com/2015/04/ecofeminist-appropriations-of-indigenous-feminisms-and-environmental-violence/.

Norrlof, Carla, 2018. Donald Trump Wants to Rewrite the Liberal Playbook that Has Kept America on Top for Decades. London School of Economics US Centre blog (February 21).

Ostrom, E., 2009a. A polycentric approach for coping with climate change. In: Background Paper to the 2010 World Development Report. The World Bank, Washington DC. http://www10.iadb.org/intal/intalcdi/PE/2009/04268.pdf.

Ostrom, E., 2010. Polycentric systems for coping with collective action and global environmental change. Glob. Environ. Chang. 20, 550-557.

Ostrom, E., 2014. A polycentric approach for coping with climate change. Ann. Econ. Financ. 15 (1), 97-134.

Oxfam, 2018. Reward Work, Not Wealth. Briefing Paper (January). http://www.oxfam. org.

Paulsen, S., 2017. Degrowth: culture, power and change. J. Polit. Ecol. 24 (1), 425-441.

Perkins, P.E., 2017. Canadian indigenous female leadership and political agency on climate change. In: Cohen, M.G. (Ed.), Climate Change and Gender in Rich Countries: Work, Public Policy and Action. Routledge, London, pp. 282-296.

Pietilä, H., 1997. The triangle of the human economy: household - cultivation - industrial production. An attempt at making visible the human economy in toto. Ecol. Econ. 20, 113-127.

Piketty, T., 2014. Capital in the Twenty-First Century. Harvard University Press, Cambridge, MA.

Plumwood, V., 1993. Feminism and the Mastery of Nature. Routledge, London.

Rose, C., 1986. The comedy of the commons: custom, commerce, and inherently public property. Univ. Chicago Law Rev. 53 (3), 711-772.

Roser, Max, 2016. Global Economic Inequality. Our World in Data. https:// ourworldindata.org/global-economic-inequality.

Roser, Max, Ortiz-Ospina, E., 2016. Income Inequality. Our World in Data. https:// ourworldindata.org/income-inequality.

Rowan, C., 2019. The new rural reconstruction movement: a Chinese grass-roots movement for environmental sustainability and social justice. Ecol. Econ (in this issue).

Salleh, A., 1997. Ecofeminism as Politics: Nature, Marx, and the Postmodern. Zed Books, London.

Salleh, A. (Ed.), 2009. Eco-sufficiency and Global Justice: Women Write Political Ecology. Pluto Press, New York.

Shimada, D., 2010. How can societies create common access to nature? In: The Roots and Development Process of the Bruce Trail, a Canadian Case Study. York University Faculty of Environmental Studies, Toronto (Post-doctoral research paper). http:// iasc2011.fes.org.in/papers/docs/356/submission/original/356.pdf.

Shiva, V., 1988. Staying Alive: Women, Ecology, and Development. Zed Books, London.

Shiva, V., Mies, M., 1993. Ecofeminism: Women, Culture, Nature. Zed Books, London.

Simpson, L., 2011. Dancing on Our Turtle's Back: Stories of Nishnaabeg Re-creation, Resurgence and a New Emergence. ARP Books, Winnipeg.

Spencer, P., Perkins, P.E., Erickson, J.D., 2018. Re-establishing justice as a pillar of ecological economics through feminist perspectives. Ecol. Econ. 152, 191-198.

Temper, Leah, 2018a. Blocking pipelines, unsettling environmental justice: from rights of nature to responsibility to territory. Local Environ. https://doi.org/10.1080/ 13549839.2018.1536698.

Temper, Leah, 2018b. Canadian clan faces gas pipelines injunction. Ecologist. https:// theecologist.org/2018/dec/06/canadian-clan-faces-oil-pipelines-injunction (6 December).

Thomson, B., 2010. Pachakuti: Indigenous perspectives, edgrowth and ecosocialism. In: Climate \& Capitalism, October 6. https://climateandcapitalism.com/2010/10/06/ pachakuti-indigenous-perspectives-degrowth-and-ecosocialism/.

Trosper, R., 2009. Resilience, Reciprocity, and Ecological Economics: Northwest Coast Sustainability. Routledge, London/New York.

Tuck, E., 2017. Can Reconciliation Take (Up) Place? ACME Lecture, Toronto. https:// www.youtube.com/playlist?list = PLRdtnJa5iycDPQ4YyfwV5YLFpo7wB_fro.

Turner, T.E., Brownhill, L.S., 2001. Gender, feminism and the civil commons: women and the anti-corporate, anti-war movement for globalization from below. Can. J. Dev. Stud. 22 (4), 805-818.

Turner, N.J., Ignace, M., Ignace, R., 2000. Traditional ecological knowledge and wisdom of aboriginal peoples in British Columbia. Ecol. Appl. 10 (5), 1275-1287.

Turner, T., Brownhill, L., Kaara, W., 2012. Degrowth? How about some de-alienation? Capital. Nat. Social. 23 (1), 93-104.

UNDP, 2015. Imbalances in paid and unpaid work. In: United Nations Development Program, Human Development Report 2015, pp. 107-130. chapter 4. http://hdr. undp.org/sites/default/files/2015_human_development_report_0.pdf.

Verma, R., 2017. Gross national happiness: meaning, measure and degrowth in a living development alternative. J. Polit. Ecol. 24 (1), 477-490.

Warren, K., 2000. Ecofeminist Philosophy: A Western Perspective on What It Is and Why It Matters, Rowman \& Littlefield; Lanham, MD.

Whyte, K.P., 2014a. Indigenous women, climate change impacts, and collective action. Hypatia 29 (3), 599-616.

Whyte, K.P., 2016. Indigenous Experience, Environmental Justice and Settler Colonialism. In: Bannon, B. (Ed.), In Nature and Experience: Phenomenology and the Environment. Rowman \& Littlefield, Lanham, MD, pp. 157-174.

Whyte, K.P., 2017a. Is it colonial déja vu? Indigenous peoples and climate injustice. In: Adamson, J., Davis, M. (Eds.), Humanities for the Environment: Integrating Knowledges, Forging New Constellations of Practice. Earthscan Publications, London/New York, pp. 88-104.

Whyte, K.P., 2017b. Indigenous climate change studies: indigenizing futures, decolonizing the Anthropocene. Engl. Lang. Notes 55 (1-2), 153-162.

Whyte, K.P., 2018a. Way beyond the lifeboat: an indigenous allegory of climate justice. In: Munshi, D., Bhavnani, K., Foran, J., Kurian, P. (Eds.), Climate Futures: Reimagining Global Climate Justice. University of California Press, Berkeley.

Whyte, K.P., 2018b. Sovereignty, justice and indigenous peoples: an essay on settler colonialism and collective continuance. In: Barnhill, A., Doggett, T., Egan, A. (Eds.), Oxford Handbook of Food Ethics, pp. 345-366.

Williams, C., 2005. A Commodified World? Mapping the Limits of Capitalism. Zed Books, London.

Wilkinson, R., Pickett, K., 2009. The Spirit Level: Why Equality Is Better for Everyone. Penguin, London/New York, London/New York.

Wily, Liz Alden, 2018. Collective land ownership in the 21st century: overview of global trends. Land 7 (68), 1-26.

Women's Earth Alliance and Native Youth Sexual Health Network, 2016. Violence on the land, violence on our bodies: building an indigenous response to environmental violence. http://landbodydefense.org/uploads/files/VLVBReportToolkit2016.pdf.

World Health Organization and World Bank, 2017. Tracking Universal Health Coverage: 2017 Global Monitoring Report.

Wu, F., 2018. China: climate justice without a social movement? In: Munshi, D., Bhavnani, K., Foran, J., Kurian, P. (Eds.), Climate Futures: Reimagining Global Climate Justice. University of California Press, Berkeley.

Xanthaki, A., 2007. Indigenous Rights and United Nations Standards: Self-determination, Culture and Land. Cambridge University Press, Cambridge. 